\section{Soviets enact new law}

\section{Moscow}

THE Supreme Soviet of the USSR has now approved a new law on AIDS and a procedure for implementing it with effect from the beginning of next year. It also intends to set up a special government commission, to be headed by a vicechairman of the Council of Ministers, to work out by then a national programme to combat AIDS.

Although the first AIDS case was registered in 1987, the order then issued by the Supreme Soviet for a national prevention programme was never implemented, according to Vladimir Pokrovsky, president of the Soviet Academy of Medical Sciences.

Even so, AIDS is not much of a problem in the Soviet Union. Since 1987, 55 million people have been checked for HIV (human immunodeficiency virus) infection, according to Igor Denisov, the newly appointed Health Minister. (He replaces Academician Yevgeny Chazov, who has resigned.) HIV infection was found in only 984 people, of whom 502 were foreign nationals. There have been 29 AIDS patients, of whom 19 have died.

Concern nevertheless persists because Soviet health-care establishments are poorly equipped and their personnel illqualified (as well as being capable of showing criminal irresponsibility and negligence). It remains horrifying that children have been infected with HIV in clinics in Elisla, Rostov-on-Don, Volgograd and Stavropol (with mothers acquiring infection from their babies). Oddly, 57 per cent of those infected with HIV are children.

The shortage of single-use syringes remains acute, with their importation limited by lack of foreign currency. The factories meant to make them under foreign licence are still not in operation. There is also an urgent need of azidothymidin (AZT), which is produced in limited quantities for lack of raw materials. The Supreme Soviet was told that a plan to produce AZT from salmon soft roe (which is plentiful at fish canneries across the country) had been considered by the Council of Ministers last year. Boris Vinogradov, a researcher from Kamchatka in the Soviet Far East, has produced a biologically active preparation from marine products. The USSR Health Ministry and the Biotechnologia Research and Production Group have shown interest in the work, but more support is needed.

Although the Soviet public has been repeatedly told that prostitution, drug addiction and homosexuality did not exist, they have in reality flourished, providing the conditions for a rapid spread of HIV. Expert forecasts, disclosed to the Supreme Soviet by Denisov, predict 1,625 cases of HIV infection by the end of this year, 24,000 by 1992 and, unless the trend is reversed, more than a million cases by 2000.

Against that sombre background, there are doubts that the new law will be sufficient, even though if differs in important ways from the 1987 ordinance. Among other things, the law will make the neglect of professional duties by medical and pharmaceutical personnel a criminal offence, as will be the disclosure of medical secrets. (Such disclosures have led to HIV carriers being ostracized and persecuted.)

But the new law will offer no guarantee of complete safety to patients at Soviet clinics and outpatient clinics. Instead, those infected with HIV at medical establishments are offered a pension before reaching retirement age, which may be poor consolation for a person undergoing treatment for, say, a duodenal disorder who acquires HIV infection in the process. It is hardly surprising, as the Supreme Soviet was told, that the press is warning readers of the dangers of the Russian obsession with seeing doctors and of asking for medication. The new law classifies infection of medical and pharmaceutical personnel with HIV as an occupational disease; such people will be entitled to various allowances and benefits.

The law also provides for the protection of the rights of HIV carriers and AIDS sufferers. They cannot be dismissed from or refused employment or admission to medical and educational establishments, nor can children be refused admission to pre-school establishments if they are HIV carriers or have AIDS. The law also prohibits other infringements of the rights and legitimate interests of HIV carriers and of their next of kin, but specifies certain benefits, such as free transportation to a place of treatment and free medicines for outpatient treatment.

But the law also demands responsible behaviour from them. Once a person knows that he (or she) is an HIV carrier or AIDS sufferer, he can be legally prosecuted for deliberately putting other persons at risk of infection.

Although the new law was approved in a now-rare display of unanimity by the Supreme Soviet, it was much debated. Thus people's deputy Yuri Shcherbak, an epidemiologist with 30 years professional experience, strongly attacked the provision in the draft law providing for obligatory check-ups of Soviet citizens and foreign nationals living in the Soviet Union.

Shcherbak's case was subtle. The draft law required that people should undergo medical checks on the decision of healthcare authorities if there were sufficient reasons to assume that they might be HIV carriers, and could be delivered to the health care establishments by order of a public prosecutor. But who will determine the sufficiency of such reasons, Shcherbak asked? Are there such reasons except the HIV test itself? This seems to be a vicious circle which can be broken only by the use of HIV tests as a preventive measure for every person at a clinic. Otherwise, that provision may lead to malpractice and turn into a kind of "punitive medicine" (as was the case with Soviet psychiatry not so long ago).

On the treatment of foreign nationals, the new law says that those who avoid checks can be deported from the Soviet Union on the decision of health-care authorities. Diplomats can be requested to undergo HIV tests only with their consent, which must be requested in advance by the Soviet Health Ministry with the Foreign Ministry.

The question also arose during the debate of the Chernobyl accident; fears were expressed that there may be a link between HIV and abnormally high exposure to radiation. Previously, it had even been suggested (but flatly rejected by most experts) that the very appearance of AIDS might be linked with enhanced radiation. Pokrovsky does not share this view, believing it to be purely theoretical.

The new law on AIDS is badly needed, but cannot by itself be a radical solution to the problem. This is why the USSR Supreme Soviet instructed the Council of Ministers to ensure the participation of Soviet research institutions in the international effort to deal with AIDS, primarily the effort to find effective methods of treatment.

Yurl Kanin Novosti

STANFORD UNIVERSITY

\section{Gorbachev thanks Panofsky \\ Washington}

SPECIAL thanks were given by Soviet President Mikhail Gorbachev to Wolfgang Panofsky, director emeritus of the Stanford Linear Accelerator Center (SLAC), Sidney Drell, deputy director of SLAC, and William Perry, professor of engineering systems, during his visit to California on 4 June. All three scientists have been associated with Stanford University's Center for International Security and Arms Control; Panofsky as a founding member, Drell as a former co-director and Perry as a codirector. Gorbachev thanked them for working with "patience and perseverance" on the "basic principles of such concepts as international security and strategic stability". His remarks came during an address at Stanford University, introduced by its president Donald Kennedy as the university with the "country's longest accelerator and its best women basketball players".

Alun Anderson 